\title{
Reproduction and its Discontents: The Forest of Symbols in Gamete Donation
}

\author{
Carles Salazar* \\ Faculty of Arts, University of Lleida, Catalonia, Spain \\ *Corresponding author: Carles Salazar, Faculty of Arts, University of Lleida, Catalonia, Spain.
}

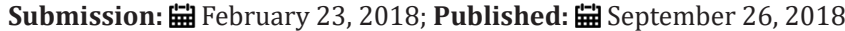

\section{Introduction}

Gamete donation is a biomedical practice the purpose of which is to enable people who suffer from certain types of infertility (specifically having to do with the quality of their gametes) to reproduce by using other people's gametes. The possibility of gamete donation originates in what we initially thought was a Western definition of family relationships, and in particular those of maternity and paternity, as love relationships. American anthropologist David Schneider defined the American family as an institution based upon two kinds of love: conjugal love and cognatic love. In gamete donation, love takes precedence over other cultural values that also participate in the definition of family relationships in Western societies, such the continuity of the bloodlines. It is not that people do not give any value to genetic continuity. However, due to the fact they find themselves in that particular situation (i.e. suffering from a kind of infertility that prevents them from using their own gametes) they decide to subordinate the value of genetic continuity to the value of love, which in this case is, in Schneider's terms, cognatic love.

This cognatic love (the love of parents for their children), which in gamete donation becomes the main constituent of family relationships at the expense of genetic continuity, has two main characteristics. First, against Schneider's culturalist approach, I do not think that cognatic love is an arbitrary cultural value but, in all probability, it is a human universal that comes from very far back in the evolutionary history of our species. Second, cognatic love is gender asymmetric: the love of a man for his children has a different origin from the love of a woman for hers. The strong attachment a woman has to the children she has born is comparable, because it has the same origin, to the attachment we find in other mammals, specifically among apes. The emergence of this mother-infant bond among mammals (and other species as well) originates in the vulnerability of infants when they are born. Because infant mammals are very vulnerable and need to be fed (and, specifically, as far as mammals are concerned, need to be fed by a female), females that developed a predisposition to attach themselves to their infants passed on their genes more successfully than those that did not develop such predisposition, since the survival of those infants was greatly increased, it was guaranteed in fact, by that attachment. $\mathrm{Ob}$ viously, for this to be the case females have to attach themselves to their infants, i.e. the infants they themselves have born and those that share with them 50 percent of their genes.
The problem is that human infants are far more vulnerable than the infant of any other species. So parental investment coming from the mother is, and has been throughout human evolutionary history, clearly insufficient to guarantee the survival of human babies. One obvious way, but by no means the only one, of making up for that parental investment deficiency in the case of humans consists in recruiting the father's services. The father shares the same number of genes with his children as the mother. So, we can speculate that a man who has an innate predisposition to look after his children has more possibilities of passing on his genes to the next generation than a man who does not have that predisposition. The problem is, however, the uncertainty that surrounds paternity.

Interestingly, there is no way a female mammal, human or non-human, can know for sure where her genes are, so she can only do that by proxy. But the proxies mother nature (natural selection) has provided female mammals with are (or have been until very recently) pretty effective, practically a hundred percent effective: pregnancy and delivery. So, there are sound reasons to believe that all female mammals are instinctively predisposed to feel a strong attachment to the babies they themselves deliver. Obviously, those proxies for gene sharing cannot be applied to fathers. The proxies for gene sharing in this case are more indirect, they can only come from pair bonding and sexual fidelity. The only way a human male can know that he is deploying his parental investment in his children is by making sure that his sexual partner did not have any affair with another man. Hence the universality of sexual jealousy, specifically male sexual jealousy.

Now gamete donation is, from this point of view, a sort of consented biological adultery. With egg donation, women attach themselves to a baby who is biologically (i.e. genetically) identical to the baby that would have been born out of an adulterous relationship between their partner and the egg donor. Similarly, with sperm donation men attach themselves to a baby genetically identical to the one who would have been born out of an adulterous relationship between their partner and the sperm donor. According to a research we conducted in two infertility clinics of Barcelona, despite this 'biological adultery', attachment apparently developed quite well among couples undergoing an infertility treatment that entailed gamete donation. We can easily explain this in terms of the argument I have developed so far. Women attach themselves to the babies born through egg donation because the cues that activate 
the mother-child bond remain intact: pregnancy and delivery. And the same applies to men in the case of sperm donation. They cannot be suspicious of any adultery because there has been no sexual relationship between their partner and the sperm donor. In fact, legally speaking, there has been no adultery.

Yet, things did not work that smoothly. The few men we interviewed whose partners had gone through an artificial insemination or IVF with a donor's sperm had in the back of their minds, in some strange way even to themselves, the feeling that they had been the victims of some sort of adultery, and hence they found it a bit difficult to attach themselves to the child (they had to really persuade themselves that the child would be 'their' child). Let us call it 'symbolic adultery'. Interestingly, the situation among women was very different. Not only there was no such feeling among the women who had received eggs from a donor (they never expressed any feeling of having been victims of an adultery between the egg donor and their partner), even though from the strictly biological point of view they found themselves in the same position as the men: they had a child that would be genetically identical to the child born out of an adulterous relationship between their partner and the egg donor. But even more intriguingly, it was the egg donors who, in some strange way even to themselves, saw themselves as some sort of 'mothers'. We shall call them 'symbolic mothers'. Let us see how these two symbolic relationships, symbolic adultery and symbolic motherhood, are constructed. We shall begin by the symbolic mothers.

Unlike sperm donation, egg donation is a rather time consuming and energy consuming process: donors' ovaries have to be stimulated, eggs are removed through surgery, etc. Many hassles are involved in egg donation for egg donors. So why do women donate their eggs? Several egg donors told us that by donating their eggs they were trying to make up or compensate for lost motherhood. Some of them, two of them to be precise, told us that they had had an abortion in the past. Both, though in different ways, they had been feeling guilt or remorse because of that, so by donating their eggs they were somehow compensating for that lost motherhood. Others told us that they wanted to have children themselves but for all sorts of different reasons, lack of a partner of simply lack of financial means to rear a child, they could not have it, so they also decided to 'be mothers' in a different way.

What explains why these women could see themselves as being 'mothers' is the same that explains why the men whose partner is undergoing an infertility treatment through sperm donation saw themselves as victims of adultery. It has to do with the sort of transaction that enables the circulation of gametes from donors to receivers and, specifically, the symbolic power of that transaction (by which I mean the power to stand for something different from itself). Notice that sperm donation is not a transaction between men, sperm donors do not donate their sperm to other men, so they can fertilise their women with it, but it is a transaction between a man (no matter how anonymous that man happens to be), the sperm donor, and a woman, the sperm receiver. That transaction is not sexual intercourse, hence there is no adultery from the legal point of view, but it is a part of what sexual intercourse amounts to. It can be seen as a metonymy for sexual intercourse since one little bit of what sexual intercourse amounts to does actually take place, i.e. the introduction of male sperm into the female body. Hence, we have one part (that does exist), sperm introduced into the female body, that stands for the whole (that does not exist), the sexual relationship. That is why sperm donation can be seen as a metonymy for sexual intercourse and hence it gives rise to symbolic adultery.

In egg donation, by contrast, the transaction is not between a woman, the egg donor, and a man. It is not a woman that gives her eggs to a man so that he can fertilise them with his sperm, even though this is what eventually will take place, but it is a transaction between two women, egg donor and egg receiver. Egg donors' symbolic motherhood is equally based on a metonymy: in this case, it is the genetic relationship between the egg donor and the child to be born out of that donation (a relation that does exist) stands for motherhood (a relation that does not exist and that normally includes gene sharing between a mother and her child but it involves more than just gene sharing: love, care, attachment, etc.). It is precisely because the transaction of gametes takes place between women, instead of between a man and a woman, that adultery, despite the existence of this metonymic motherhood, cannot be symbolised.

In this way, I have tried to combine a simultaneously biological and symbolic approach to the study of gamete donation. I think gamete donation should be seen within a wider relational framework, the relational framework provided by a kinship system. And human kinship is, it seems to me, simultaneously biology (evolution, if you like) and symbolism (you can call it 'culture').
Creative Commons Attribution 4.0 International License

For possible submissions Click Here
Submit Article

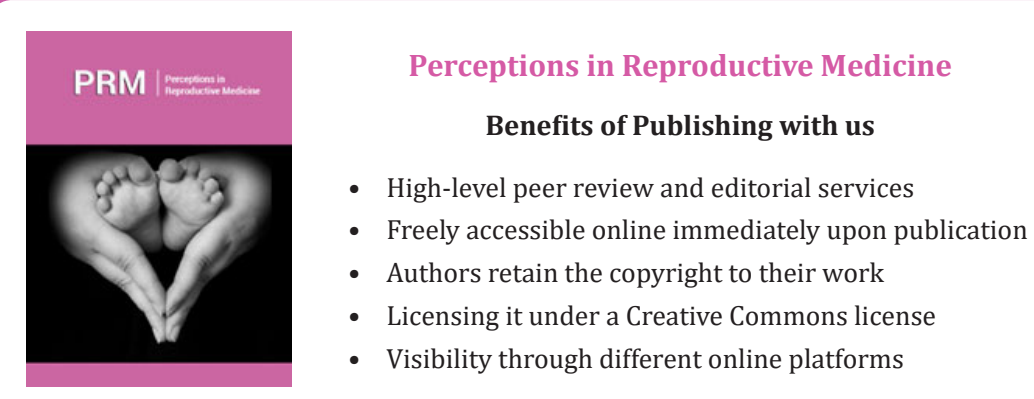

How to cite this article: Carless S. Reproduction and its Discontents: The Forest of Symbols in Gamete Donation. Perceptions Reprod Med. 2(5) PRM.000550.2018. DOI: 10.31031/PRM.2018.02.000550 